\title{
Pendampingan Partisipatori dalam Meningkatkan Kemandirian Masyarakat Tunagrahita
}

\author{
Kapit Tatak Aprianto ${ }^{1}$, Ach. Rasyad ${ }^{1}$, Zulkarnain ${ }^{1}$ \\ ${ }^{1}$ Pendidikan Luar Sekolah-Universitas Negeri Malang
}

\section{INFO ARTIKEL}

\section{Riwayat Artikel:}

Diterima: 24-04-2019

Disetujui: 24-06-2019

Kata kunci:
participatory assistance;
independence;
mentally disabled;
pendampingan partisipatori;
kemandirian;
tunagrahita

independence

mentally disabled

kemandirian;

\begin{tabular}{l}
\hline INFO ARTIKEL \\
\hline Riwayat Artikel: \\
Diterima: $24-04-2019$ \\
Disetujui: $24-06-2019$ \\
\hline
\end{tabular}

\begin{abstract}
ABSTRAK
Abstract: This research aims to describe community participatory accompaniment for mental retardation community implemented by Pokmas Karanpatihan Bangkit. The research are using qualitative approachs and case studies. This research approach was interactive model analysis. The research results are: Participatory accompaniment in Karangpatihan village was conducted by involving the community. In the estamblishment of Pokmas Karangpatihan Bangkit by involving eight communities Karangpatihan village as assessor such as Karang Taruna and community local point, closed family of mental retardation community. Participatory accompaniment was conducted to improve the ability throughout the catfish cultivation training, and goats, the training to make some handicraft such as doormat and batik Ciprat. The accompaniment has impacted Karangpatihan village which commonly named as an idiot community. Furthermore, it has impacted to community economics as well as to their daily life.
\end{abstract}

\begin{abstract}
Abstrak: Penelitian ini bertujuan untuk mendeskripsikan mengenai pendampingan partisipatori masyarakat untuk masyarakat tunagrahita yang dilakukan oleh Lembaga Pokmas Karanpatihan Bangkit. Penelitian ini menggunakan pendekatan penelitian kualitatif dan studi kasus. Penelitian ini menggunakan analisis Interactive Model. Hasil analisis data tersebut, diperoleh simpulan hasil temuan penelitian, yaitu pendampingan partisipatori di desa Karangpatihan dilakukan dengan melibatkan masyarakat. Dalam pembentukan Pokmas Karangpatihan Bangkit dengan melibatkan delapan masyarakat desa karangpatihan sebagai pendamping, seperti karangtaruna, dan tokoh masyarakat, keluarga terdekat masyarakat tunagrahita. Pendampingan partisipatori dalam meningkatkan kemampuan melalui pelatihan-pelatihan budidaya ayam, lele, dan kambing, serta pelatihan-pelatihan pembuatan kerajinan berupa keset dan batik ciprat. Hasil dari pendampingan partisipatori masyarakat tunagrahita adalah kerajinan keset dan batik ciprat. Pendampingan juga berdampak pada sebutan desa Karangpatihan yang dikenal dengan kampung idiot. Selain itu, berdampak pada ekonomi dan kehidupan sehari-hari masyarakat.
\end{abstract}

\section{Alamat Korespondensi:}

Kapit Tatak Aprianto

Pendidikan Luar Sekolah

Universitas Negeri Malang

Jalan Semarang 5 Malang

E-mail: kapitplsuma@gmail.com

Manusia merupakan makhluk sosial yang membutuhkan satu dengan lainnya. Setiap apa yang dilakukan oleh manusia pasti berhubungan dengan yang lainnya. Hal itu juga terjadi dalam mencapai sebuah kesejahteraan hidup, bahwa untuk mencapai kesejahteraan tidaklah dapat melakukan sendiri pasti ada pihak lain yang membantu. Interaksi akan berjalan dengan baik apabila mempunyai kemampuan berbahasa dan daya pikir yang sama, namun akan berbeda jika interaksi dengan meraka yang mempunyai kekurangan secara fisik dan daya pikir yang lemah. Kemandirian masyaarakat timbul dengan adanya dorongan dari luar sehingga masyarakat mempunyai keberanian untuk meningkatkan kemampuan atau potensi-potensi yang ada. Dalam meningkatkan kemandirian perlu adanya pendamping yang memfasilitasi agar tercapai tujuan untuk meningkatkan kemandirian masyarakat. Menurut (Sumpeno, 2009) upaya memberdayakan masyarakat, istilah fasilitasi digunakan di kalangan praktisi dan aktivis lembaga swadaya masyarakat, organisasi non pemerintahan, dan nongovernment organizations sebagai sebuah bentuk dukungan untuk meningkatkan kemampuan-kemampuan individu, kelompok, atau kelembagaan dalam masyarakat. Fasilitasi merupakan salah satu kegiatan penting yang dilakukan oleh pendamping. Dengan ada yang memfasilitasi yang disebut pendamping dapat memberikan dukungan dan diharapkan mampu meningkatkan kemandirian dan kesejahteran masyarakat. 
Desa Karangpatihan pada saat ini memiliki jumlah penduduk 5746 jiwa, terbagi atas laki-laki 2924 jiwa dan perempuan 2826 jiwa. Luas desa Karangpatihan 1336,6 ha dengan jumlah empat dusun, meliputi Krajan, Bribis, Bendo, dan Tanggungrejo. Sebelah utara berbatasan dengan desa Jonggol kecamatan Jambon, sebelah timur berbatasan dengan desa Sumberejo Kecamatan Balong, sebelah selatan desa Ngendut Kecamatan Balong, dan sebelah Barat dibatasi dengan Hutan Negara/Kabupaten Pacitan. Berdasarkan pengamatan studi pendahuluan bahwasannya mayoritas masyarakat desa Karangpatihan bermata pencaharian sebagai petani.

Desa Karangpatihan Kecamatan Balong Kabupaten Ponorogo adalah desa yang penduduknya banyak mengalami keterbelakangan mental atau tunagrahita. Berdasarkan studi pendahuluan bahwa dari jumlah penduduk 5746 jiwa di desa karangpatihan terdapat 98 warga yang mengalami keterbelakangan mental atau tunagrahita, kini desa Karangpatihan diberikan sebutan dengan "Kampung Idiot". Dari informasi yang ada berdasarkan studi pendahuluan, dahulu banyak penduduk desa Karangpatihan yang mengalami keterbelakangan mental karena sekitar tahun 1980an masyarakat banyak yang kekurangan yodium. Dengan kondisi lahan yang sulit ditanami padi maka masyarakat bertani ketela. Dari ketela itu masyarakat menjadikan ketela menjadi makanan utama, agar ketela dapat bertahan lama, masyarakat menjadikan ketela menjadi "gaplek" atau "tiwul" yang menjadi makanan setiap hari masyarakat desa Karangpatihan.

Kondisi masyarakat desa Karangpatihan ketika itu sangatlah memprihatinkan, namun hal itu tidak menjadi penghalang kepala desa untuk menyejahterahkan masyarakat tunagrahita. Kepala desa berinovasi membuat sebuah Lembaga Pemberdayaan Masyarakat untuk mendampingi masyarakat tunagrahita dalam mencapai kemandirian dan kesejahteraan. Lembaga yang didirikan diberi nama Lembaga Pokmas (Kelompok Masyarakat) Karangpatihan Bangkit terbagi menjadi beberapa pengurus di antaranya, ketua, sekertaris, dan bendahara. Dalam meeningkatkan kesejahteraann masyarakat dibangunlah sebuah tempat yang dijadikan tempat berkumpul, rapat, tempat pelatihan, dan kegiatan masyarakat yaitu dengan nama Rumah Harapan Karangpatihan Bangkit. Rumah Harapan Karanpatihan Bangkit dibentuk kepengurusan yang bertujuan untuk mengelola rumah. Pengurus Karangpatihan Bangkit terdiri dari ketua, administrasi umum, bendahara, bagian produksi, bagian pemasaran, dan bagian kemitraan.

Tujuan dibentuknya lembaga ini adalah untuk mendampingi dan memfasilitasi masyarakat tunagrahita dalam meningkatkan kesejahteraan masyarakat. Peran lembaga Pokmas Karangpatihan sangat penting dalam meningkatkan kesejahteraan dan kemandirian masyarakat. Menurut (Sumpeno, 2009) peran fasilitator atau pendamping adalah sebagai trainer tugasnya dalam membimbing, konsultasi, coaching dan pemberi materi untuk meningkatkan kemampuan dan berubahnya perilaku pembelajar. Upaya untuk meningkatkan kemandirian masyarakat sesuai dengan kajian ruang lingkup Pendidikan Luar Sekolah melalui pendidikan non-formal maupun informal. Menurut (Moedzakir, 2010) menjelaskan bahwa tujuan pemberdayaan masyarakat maupun tujuan pendidikan pada dasarnya memiliki kesamaan, yaitu mengembangkan potensi manusia.

Berdasarkan hal diatas, peneliti tertarik untuk meneliti tentang pendampingan masyarakat. Pendampingan masyarakat tersebut akan diteliti secara mendalam bagaimana pendampingan partisipatori masyarakat dilihat dari bagaimana pemerintah desa meningkatkan partisipasi masyarakat tunagrahita. Oleh karena itu, peneliti ingin meneliti dengan judul "Pendampingan partisipatori dalam meningkatkan Kemandirian Masyarakat Tunagrahita". Alasan peneliti melakukan penelitian ini adalah adanya fenomena yang menarik untuk diteliti yaitu selama ini banyak yang memandang dengan sebelah mata masyarakat tunagrahita, namun hal lain berbeda dengan di desa Karangpatihan yang memberdayakan masyarakat tunagrahita melalui pendampinganpendampingan. Oleh karenanya peneliti tertarik meneliti secara mendalam mengenai pendampingan partisipatori yang dilakukan dilihat dari bagaimana proses pendampingan partisipatori, bentuk-bentuk kemampuan yang diajarkan, dan hasil serta dampak pendampingan partisipatori yang dilakukan. Kemudian, alasan berikutnya adalah pendampingan yang dilakukan oleh masyarakat tunagrahita masuk dalam kajian pendidikan luar sekolah berdasarkan studi pendahuluan di desa Karangpatihan. Di dalam (UU Nomor 20 Tahun 2003 Tentang Sistem Pendidikan Nasional). Berdasarkan hal tersebut, penelitian ini sangat menarik diteliti melalui kajian-kajian pendidikan luar sekolah.

Dalam penelitian ini peneliti membandingkan penelitian terdahulu yang berhubungan dengan masyarakat tunagrahita. Tujuan peneliti membandingkan dengan penelitian terdahulu yaitu untuk menghasilkan penelitian yang tidak sama dengan penelitian lain juga untuk menambah wawasan peneliti. Peneliti ingin meneliti secara mendalam mengenai pendampingan partisipatori masyarakat dalam meningkatkan kemandirian masyarakat tunagrahita. Dari ketiga penelitian diatas dapat disimpulkan bahwa penelitian terdahulu berbeda penelitian yang akan dilakukan oleh peneliti. Perbedaan tersebut terletak pada fokus penelitian yang digunakan sebagai dasar pengambilan data di lapanggan. Fokus penelitian ini secara umum adalah pendampingan partisipatori dalam meningkatkan Kemandirian Masyarakat Tunagrahita.

\section{METODE}

Secara metodologis pendekatan penelitian ini adalah kualitatif dengan jenis penelitian studi kasus. Dalam penelitian ini, peneliti mendeskripsikan dan menjelaskan terkait dengan pendampingan partisipatori masyarakat dalam meningkatkan Kemandirian Masyarakat Tunagrahita yang dihasilkan melalui pengumpulan data baik secara lisan, tulis, maupun pengamatan yang berada di lokasi penelitian. Dalam proses penelitian ini, peneliti mempunyai peran utama mulai tahap perencanaan, 
pelaksanaan, dan tindak lanjut berupa penafsiran maupun laporan hasil penelitian. Hal ini diperkuat oleh (Bogdan \& Biklen, 1982) menyatakan bahwa peneliti merupakan instrumen utama (key instrument) dan harus bertindak, yaitu menjadi perencana, pengumpul data, menganalisa data, dan pelapor hasil penelitian. Dalam penelitian ini, informasi yang digali secara mendalam berkaitan dengan bagaimana pendampingan partisipatori masyarakat dalam meningkatkan kemandirian masyarakat tunagrahita.

Berdasarkan fokus penelitian, maka peneliti berusaha mengumpulkan data secara lengkap dan mendalam. Sumber data ini merupakan segala sesuatu yang digunakan dan dapat dimanfaatkan untuk memberikan informasi secara lengkap dan terperinci terkait dengan apa yang butuhkan dalam menjawab fokus masalah penelitian. Informan dalam penelitian ini adalah (1) Bapak Eko Mulyadi, selaku pengawas Lembaga Pokmas Karangpatian Bangkit dan sebagai Kepala Desa Karangpatian. (2) Bapak Samuji, selaku ketua Lembaga Rumah Harapan Karangpatian Bangkit, (3) Bapak Teguh Cahyono Ketua POKMAS Karangpatihan Bangkit, dan Bapak Gito selaku Bagian Pendamping di Lembaga Rumah Harapan Karangpatihan Bangkit. Hasil dari wawancara sangatlah penting untuk mendukung penelitian yang dilakaukan, maka dalam penelitian ini dilakukan wawancara lebih dari satu informan untuk mencapai hasil yang mendalam.

Prosedur pengumpulan data dilakukan peneliti sendir, yakni dimana instrumen kunci secara langsung mendatangi informan di tempat penelitian. Pengumpulan data dalam penelitian ini dilakukan dengan menggunakan teknik (a) wawancara, (b) observasi, dan (c) studi dokumentasi. Penelitian kualitatif menuntut penggunaan multi teknik pengumpulan data dan multi sumber data. Dalam hal ini dituntut untuk memperoleh gambaran yang menyeluruh (holistik) tentang sasaran penelitian sehingga informasi yang dibutuhkan bukan hanya substansinya saja, melainkan juga konteksnya.

Teknik analisis data merupakan kegiatan setelah data dari seluruh atau sumber data lain terkumpul. Kegiatan dalam analisis data adalah mengelompokkan data berdasarkan pertanyaan. Bentuk analisis data pada penelitian ini menggunakan analisis data interaktif. Analisis data adalah salah satu tahap dalam penelitian yang dilakukan guna mengelola data yang terkumpul melalui proses wawancara, observasi, dan studi dokumen yang telah dilakukan pada tahap pengumpulan data. (Miles, Huberman, Huberman, \& Huberman, 1994) menjelaskan "our definition of data analisis contains three linked subprocesses, data reduction, data display, and conclusions drawing/verification". Berdasarkan hal diatas bahwa analisis data mengandung tiga subproses yaitu data reduction, data display, and conclusions drawing/verification.

Pengecekan keabsahan temuan dalam penelitian kualitatif penting untuk dilakukan agar temuan penelitian dapat dipertanggungjawabkan. Ada empat kriteria yang digunakan pada pengecekan keabsahan temuan dalam penelitian kualitatif, yaitu derajat kepercayaan (credibility), dapat tidaknya temuan ditransfer ke latar lain (transferability), ketergantungan pada konteksnya (dependability), dan dikonfirmasikan pada sumbernya (confirmability). Derajat kepercayaan (credibility) digunakan untuk membuktikan bahwa data yang ditemukan di lapangan memiliki nilai kebenaran/kredibel untuk menjamin keabsahan data. Uji validitas pada penelitiani menggunakan teknik antara lain perpanjangan kehadiran di lapangan, observasi yang diperdalam, triangulasi (menggunakan beberapa sumber, metode, teori), pembahasan sejawat, analisis kasus negatif, pelacakan kesesuaian hasil, dan pengecekan anggota. Dari ketujuh teknik tersebut dipergunakan untuk menguji derajat kepercayaan dengan menggunakan teknik (1) perpanjangan kehadiran peneliti di lapangan, (2) observasi yang diperdalam, dan (3) triangulasi. Teknik perpanjangan kehadiran di lapangan dilakukan dengan tujuan mendapatkan data pendukung yang dapat menguatkan data yang telah diperoleh agar kredibilitasnya dapat dipertanggungjawabkan.

\section{HASIL}

Proses Pendampingan Partisipatori dalam Meningkatkan Kemandirian Masyarakat Tunagrahita

Kegiatan pendampingan sudah dilakukan EM semenjak SMA dengan mencarikan bantuan sederhana untuk masyarakat tunagrahita. dengan proses yang lama kemudian mendirikan lembaga Pokmas Karangpatihan Bangkit. Dalam pembentukan POKMAS Karangpatihan Bangkit melibatkan masyarakat pada umumnya, seperti karangtaruna dan tokoh masyarakat. Tokoh masyarakat dan karangtaruna merupakan faktor penting dalam pendampingan masyarakat. Dengan adanya masyarakat dan karangtaruna maka memberikan dorongan motivasi untuk masyarakat sehingga masyarakat tunagrahita dihargai oleh masyarakat pada umumnya.

Pendampingan terhadap masyarakat tunagrahita itu dipelopori oleh EM sebagai masyarakat biasa ketika itu kemudian diangkat menjadi Kepala desa Karangpatihan. EM melakukan pendampingan semenjak ketika masih SMA dengan memberikan bantuan-bantuan sederhana. Pendampingan pada dasarnya akan mudah jika bisa diterima dengan sasaran yang mau didampingi, hal itu akan mempermudah bagaimana pendamping memberikan ilmu atau materi pada sasaran pendampingan. Keberhasilan pendamping tidaklah singkat memerlukan proses yang lama dan kesabaran dalam mendampingi masyarakat tunagrahita. Proses pendampingan masyarakat tunagrahita dilakukan secara intensif dengan mendatangi rumah masyarakat tunagrahita. Proses tersebut dilakukan berulang-ulang untuk memberikan pemahaman dan kebiasaan kepada masyarakat tungrahita. Pendampingan di desa Karangpatihan atau dikenal dengan "kampung idiot" sudah cukup lama. Pertama kali memberikan pendampingan dengan mencarikan donatur-donatur yang memberikan bibit lele, ayam, dan kambing yang kemudian dibentuk sebuah Lembaga untuk mendampingi masyarakat tunagrahita. Proses pendampingan dilakukan terus menerus secara intensif. Pendampingan dilakukan dengan mendatangi ke rumah-rumah warga tunagrahita, dan juga dipusatkan di rumah warga untuk kerajinan pembuatan keset. 
Namun, setelah dibangunnya rumah harapan Karangpatihan Bangkit maka kegiatan dipindahkan di rumah Karangpatihan Bangkit. Pembangunan rumah harapan Karangpatihan Bangkit merupakan bentuk partisipatori masyarakat dalam membantu masyarakat tunagrahita. POKMAS Karangpatihan Bangkit bekerjasama dengan BBRSBG Temanggung melakukan pemberdayaan masyarakat tunagrahita dengan memberikan pelatihan langsung maupun pelatihan bagi pendamping.

\section{Kemampuan yang diajarkan Pendampingan Partisipatori dalam Meningkatkan Kemandirian Komunitas Tunagrahita}

Pendamping di desa Karangpatihan tidak mempunyai lulusan pendidikan. Namun, dengan keterbatasan pendidikan pendamping melakukan pendampingan dengan modal keberanian dan ketulusan. Dengan keterbatasan, pendidikan pendamping memberikan pelatihan-pelatihan dari berternak, ayam, lele, dan kambing, sampai pembuatan kerajinan seperti tasbih, keset, dan batik ciprat. Pendamping memberikan klasifikasi kepada masyarakat tunagrahita. Klasifikasi terbut terdiri dari masyarakat tungarahita keterbelakanagan mental ringan, sedang, dan berat.

Pembelajaran dalam pendampingan masyarakat tunagrahita menggunakan pendekatan, pemahaman, dan penekanan. Selain dengan tiga pendekatan tersebut, Pokmas Karangpatihan Bangkit melakukan pendekatan dengan mengobrol secara intensif. Kegiatan pembelajaran yang dulunya masih menumpang sekarang dilaksanakan di rumah harapan Karangpatihan Bangkit. Pendampingan yang dilaksanakan setiap hari rabu di rumah harapan Karangpatihan Bangkit dengan mengumpulkan masyarakat tunagrahita. Komunikasi menjadi salah satu kendala dalam pembelajaran karena setiap masyarakat tunagrahita mempunyai gaya komunikasi yang berbeda-beda dengan kendala yang dihadapi pendamping dapat terselesaikan dengan pendekatan dan pembiasaan gaya komunikasi masyarakat tunagrahita.

\section{Hasil dan Dampak Pendampingan Partisipatori Masyarakat dalam Meningkatkan Kemandirian Masyarakat Tunagrahita}

Pendampingan partisipatori mempunyai hasil dan dampak pada masyarakat tunagrahita. Hasil dari pendampingan partisipatori masyarakat tunagrahita adalah kerajinan-kerajinan yang dilatihkan oleh pedamping untuk meningkatkan pendampatan masyarakat berupa kerajinan keset dan batik ciprat. Pendapatan masyarakat dari hasil kerajinan tidak menentu dikarenakan faktor psikologi masyarakat tunagrahita. Semakin banyak hasil kerajinan yang dibuat oleh masyarakat semakin banyak upah yang diterima masyarakat dari pembuatan kerjinan. Uraian diatas merupakan hasil dari pendampingan yang dilakukan. Selain hasil pendampingan, pendampingan juga berdampak pada sebutan desa karangpatihan yang dikenal dengan "kampung idiot". Dengan pendampingan yang dilakukan mampu memberikan kesempatan masyarakat untuk memenuhi kebutuhan masyarakat secara mandiri, yaitu berupa pupuk tanaman dan kebutuhan pokok lainnya.

\section{PEMBAHASAN}

\section{Proses Pendampingan Partisipatori dalam Meningkatkan Kemandirian Masyarakat Tunagrahita}

Pendampingan tidak terlepas dari pihak luar yang membantu untuk melaksanakan pendampingan. Dalam pelaksanaan pendampingan masyarakat, pendamping kegiatan melibatkan masyarakat seringkali disebut partisipatori. Menurut (Made, 1988) partisipatoris tidak terlepas dari partisipasi yaitu pelibatan beberapa orang dalam suatu kegiatan. Berdasarkan uraian diatas dapat diartikan dalam kegiatan pendampingan dibutuhkan sebuah pelibatan masyarakat untuk mensukseskan kegiatan yang akan direncanakan. Partisipatori dekat dengan istilah partisipasi, namun dari dua kata diatas mempunyai arti yang berbeda. Partisipatori merupakan pelibatan masyarakat pada umumnya dalam suatu kegiatan awal hingga akhir. Berdasarkan uraian diatas sesuai den gan yang disampaikan (Britha, 1999) bahwa dalam pandangan pembangunan partisipatori ada dua perspektif (1) keterlibatan masyarakat setempat dalam pemilihan, perencangan, perencanaan dan pelaksanaan dan evaluasi program atau proyek yang akan dilaksanakan masyarakat; (2) membuat umpan balik (feedback) yang merupakan tanggapan dari masyarakat.

Pendampingan partisipatori merupakan pendampingan yang melibatkan masyarakat untuk mendampingi masyarakat yang menjadi dampingan. Pendampingan partisipatori melibatkan masyarakat desa Karanpatihan bertujuan untuk meningkatkan kemandirian masyarakat tunagrahita yang dilakukan sejak lama dengan mencarikan bantuan-bantuan donator untuk membantu masyarakat tunagrahita. Dalam pembentukan Pokmas Karangpatihan Bangkit melibatkan delapan masyarakat desa Karangpatihan sebagai pendamping, seperti karangtaruna dan tokoh masyarakat. Tokoh masyarakat dan karangtaruna merupakan faktor penting dalam pendampingan masyarakat. Dengan adanya masyarakat dan karangtaruna, maka memberikan dorongan motivasi untuk masyarakat sehingga masyarakat tunagrahita dihargai oleh masyarakat pada umumnya.

Uraian di atas sesuai dengan yang disampaikan (Totok \& Poerwoko, 2015) tentang konsep pemberdayaan bahwa pemberdayaan adalah suatu upaya yang dilaksanakan masyarakat dengan bantuan atau tanpa bantuan pihak luar, untuk meningkatkan kehidupannya yang berbasis kepada potensi dan kemampuan mereka sendiri, melalui optimasi kemampuan serta peningkatan nilai tawar yang dimiliki oleh masyarakat. Dengan kata lain, pemberdayaan menempatkan kekuatan masyarakat sebagai modal utama serta menghindari rekayasa pihak luar yang sering kali mematikan kemandirian masyarakat setempat. Dengan demikian, dapat disimpulkan bahwa proses pendampingan yang dilakukan oleh Pokmas Karangpatihan secara teori sesuai dengan pemberdayaan upaya yang dilakukan oleh masyarakat untuk meningkatkan hidup masyarakat yang akan diberdayakan. 
Masyarakat sekitar atau masyarakat daerah itu sendiri menjadi modal dalam pemberdayaan yang dilakukan dengan pendampingan-pendampingan, pendampingan menjadi salah satu langkah dalam memberdayakan masyarakat. Pendampingan partisipatori menjadi sangat penting dalam melaksanakan konsep pemberdayaan masyarakat. Oleh sebab itu, Pokmas Karangpatihan Bangkit dibentuk dengan pelibatan masyarakat yaitu karangtaruna dan tokoh masyarakat. Pada tahun 2013 pak Eko mempelopori berdirinya Pokmas Karangpatihan. Dengan bantuan dari donator, maka pada tahun 2016 mendirikan rumah karangpatihan sebagai pusat kegiatan masyarakat tunagrahita. Dengan demikian, dapat disimpulkan bahwa kegiatan pendampingan di desa Karangpatihan dilakukan terus menerus secara intensif dengan gotong royong warga Karangpatihan Bangkit dan melibatkan masyarakat sekitar.

\section{Kemampuan yang diajarkan Pendampingan Partisipatori dalam Meningkatkan Kemandirian Komunitas Tunagrahita}

Pendidikan non-formal dan informal adalah pendidikan yang sesuai diterapkan dalam memandirikan masyarakat tunagrahita. Masyarakat tunagrahita adalah masyarakat yang perlu diberikan dukungan sehingga mampu secara mandiri dapat memenuhi kebutuhan pribadi masyarakat tunagrahita. Menurut (Listiyaningsih \& Dewayani, 2009) tunagrahita adalah anak yang mempunyai kemampuan intelektual atau berpikir dan keterampilan dibawa rata-rata teman seusianya. Masyarakat tunagrahita merupakan masyarakat yang perlu diberdayakan dengan pedekatan yang berbeda dengan masyarakat lainnya. Pendidikan merupakan salah satu cara untuk memberdayakan masyarakat tunagrahita. Pendidikan yang diterapkan tentunya berbeda dengan pendidikan yang dilaksanakan pada umumnya, dalam pendidikan anak tunagrahita diperlukan pelayanan khusus sehingga masyarakat tunagrahita mudah dalam memahami materi-materi yang disampaikan. (Rochyadi, 2012) menyatakan hal yang penting dalam mendidik anak tunagrahita adalah masyarakat tidak mengisolasi anak tunagrahita karena mereka terbukti mampu melakukan sesuatu sehingga memunculkan harga diri dan tidak menarik diri dari lingkungan. Berdasarkan kutipan diatas bahwa anak tungarahita memerlukan tempat di masyarakat sehingga masyarakat tidak mempunyai rasa takut untuk berkomunikasi dengan lingkungan masyarakat.

Pendidikan secara non-formal dan informal merupakan salah satu langkah untuk memberdayakan masyarakat tunagrahita. Pendidikan non-formal dan informal merupakan pendidikan proses pembelajarannya dilaksanakan diluar sistem formal pendidikan non-formal dan informal menjadi sangat sesuai dengan masyarakat tunagrahita karena dalam prakteknya lebih fleksibel dan berupa pelatihan-pelatihan yang berkelanjutan. Menurut (Oktavini \& Irdamurni, 2013) menjelaskan metode ceramah, demonstrasi dan latihan dapat membantu anak dalam miningkatkan kemampuan anak tunagrahita karena dalam pembelajaran dapat dilihat, ditiru, dan dipraktikkan. Pada proses pendidikan melalui pelatihan, ceramah atau demontrasi masyarakat tunagrahita mampu mempraktikkan secara langsung apa yang sedang dipelajari sehingga pendamping mampu memberikan arahan dan membetulkan secara langsung sehingga tingkat pemahaman akan lebih paham, dapat disimpulkan peran pendamping sangat penting dalam penyampaian pembelajaran.

Pokmas Karangpatihan bangkit dalam proses pendampingan dilakukan secara intensif dan keberlanjutan. Pendampingan dilakukan dengan mendatangi rumah-rumah, kegiatan pendampingan yang dilakukan oleh POKMAS Karangpatihan Bangkit dibantu oleh donator-donatur sehingga kegiatan pendampingan berjalan lancar. Setiap pendampingan melibatkan masyarakat setempat untuk membantu berjalannya pendampingan. Tidak hanya masyarakat setempat, namun dengan keluarga terdekat masyarakat tunagrahita. Pelibatan tersebut ditujukan untuk mempermudah dalam penyampaiannya. Sikap pendamping saat pendampingan dilakukan dengan santai tanpa ada diskriminasi yang dilakukan oleh pendamping. Proses itu dilakukan oleh pendamping berulang-ulang sampai masyarakat tunagrahita memahami maksud yang disampaikan oleh pendamping. Pelatihanpelatihan dan kunjungan ke rumah dilakukan tidak hanya sekali untuk menimbulkan pemahaman pada masyarakat tunagrahita, tetapi dilakukan lebih dari satu kali. Hal tersebut dilakukan agar masyarakat tunagrahita memahami dengan baik pelatihan yang sudah diberikan.

Peningkatan perkembangan atau peningkatan kemandirian masyarakat membutuhkan layanan-layanan yang intensif untuk masyarakat tunagrahita. Pendampingan partisipatori secara intensif merupakan bentuk layanan-layanan yang dilakukan oleh Pokmas Karangpatihan Bangkit dalam memandirikan masyarakat tunagrahita. Pendampingan partisipatori intensif diterapkan dengan bentuk intensitas pendamping melakukan pendampingan dengan mendatangi ke rumah-rumah masyarakat tunagrahita yang bertujuan untuk memberikan pemahaman-pemahaman pada masyarakat tunagrahita. Pelatihan-pelatihan juga dilaksanakan dalam meningkatkan kemandirian masyarakat. Kegiatan pelatihan pada masyarakat tunagrahita dilaksanakan tidak hanya dilakukan sekali atau dua kali. Kegiatan pelatihan-pelatihan dilakukan secara terus menerus sampai masyarakat tunagrahita paham dan menunjukkan sikap kebiasaan yang ditunjukkan tanpa adanya instruksi pendamping atau bantuan luar secara otomatis memahami apa yang harus dilakukan.

Pendampingan dalam meningkatkan kemampuan melalui pelatihan-pelatihan budidaya ayam, lele, dan kambing, serta pelatihan-pelatihan pembuatan kerajinan berupa keset dan batik ciprat. Pendamping mengklasifikasikan atau mengelompokkan masyarakat tunagrahita menjadi tiga, yaitu ringan, sedang, dan berat. Dalam pengelompokan ketiga kategori masyarakat tunagrahita berbeda dengan teori pengelompokkan masyarakat tunagrahita. Pada dasarnya, pengelompokan berbeda dalam cakupan pembuatan istilah. Pokmas Karangpatihan secara sederhana menggelompokkan masyarakat tunagrahita dengan kategori 
ringan, sedang, dan berat. Namun, secara teori masyarakat tunagrahita dikelompokkan dengan kategori masyarakat Tunagrahita mampu didik, mampu latih, dan mampu rawat. Penggelompokkan tersebut mempunyai perbedaan dalam penyebutannya, namun mempunyai istilah yang sama. Masyarakat tunagrahita kategori ringan, yang disebut masyarakat tunagrahita mampu didik (debil) orang yang mempunyai IQ 50-75. Dalam mendampingi masyarakat tunagrahita, Pokmas Karangpatihan mampu mendidik dengan memberikan pelatihan-pelatihan budidaya lele, ayam, dan kambing serta memberikan pelatihan ketrampilan, seperti pembuatan keset dan batik ciprat. Masyarakat keterbelakangan mental ringan bisasanya masih bisa melakukan pekerjaanpekerjaan yang ringan, seperti mencari rumput dan menjadi buruh tani. Masyarakat tunagrahita dengan kategori sedang atau yang disebut, Tunagrahita mampu latih (imbecil) merupakan Tunagrahita yang mempunyai IQ 25-50. Tunagrahita mampu latih (Imbecil) dikelompokan menjadi anak yang mampu latih, dimana mereka dapat dilatih untuk beberapa ketrampilan tertentu sama halnya dengan tunagrahita mampu didik, dalam mendampingi tunagrahita Pokmas Karangpatihan Bangkit memberikan pelatihanpelatihan kerajinan keset, dan pembuatan batik ciprat.

Dalam kehidupannya, masyarakat tunagrahita memiliki kecenderungan untuk melakukan kegiatan-kegiatan yang dia sukai, lebih cenderung kepada kerajinan-kerajinan, namun dalam berpikir dibandingan masyarakat tunagrahita ringan lebih rendah daya tangkapnya. Masyarakat tunagrahita dengan kategori berat atau tunagrahita mampu rawat (idiot) adalah orang yang mempunyai IQ dibawah 25. Dalam kehidupan sehari-hari sangat membutuhkan bantuan dari orang lain. Sehingga dalam pendampingan yang dilakukan yaitu membantu memenuhi kebutuhan hidup dengan memberikan bantuan bahan pokok yang bertujuan untuk menjaga tercukupinya asupan gizi pada masyarakat tunagrahita. Pokmas Karangpatihan menggunakan tiga pendekatan, yaitu pendekatan, pemahaman, dan penekanan dalam mendampingi masyarakat tunagrahita. Ketiga pendekatan ini dilakukan untu memberikan pengetahuan baru masyarakat dengan metode ceramah dengan isyarat, pelatihan yang dilakukan secara berulang ulang. Pendampingan yang dilakukan oleh Lembaga Pokmas Karangpatihan Bangkit dilakukan secara berulangulang menunjukan bahwa pendampingan partisipatori sesuai dengan teori pendampingan developmental yaitu pendampingan dengan berkelanjutan. Pendampingan partisipatori developmental menggunakan tiga pendekatan di atas yang dilakukan secara berulang ulang sampai masyarakat yang didampingi memahami materi yang disampaikan.

\section{Hasil dan Dampak Pendampingan Partisipatori Masyarakat dalam Meningkatkan Kemandirian Masyarakat Tunagrahita}

Hasil dari pendampingan partisipatori adalah perubahan kehidupan masyarakat yang dulunya masyarakat tunagrahita hanya berpangku tangan mengharapakan belas kasihan dari orang lain sekarang telah mampu menghasilkan produk-produk yang dijadikan tambahan pemasukan bagi masyarakat tunagrahita. (Jamaris, 2016) menjelaskan pendampingan pada dasarnya merupakan upaya untuk mengajak serta dan membimbing masyarakaat (individu atau kelompok) untuk mengembangkan berbagai potensi yang dimiliki agar mencapai kualitas hidup yang baik. Berdasarkan paparan di atas dapat disimpulkan bahwa pendampingan mampu mengahasilkan produk-produk kerajianan yang dapat membantu kehidupan masyarakat. Fungsi pendampingan adalah upaya yang dilakukan oleh pendampingan untuk meningkatkan kualitas kehidupan yang baik. Upaya-upaya yang dilakukan oleh Pokmas Karangpatian Bangkit merupakan bentuk usaha untuk meningkatkan kualitas hidup masyarakat tunagrahita dengan memberikan pelatihan-pelatihan kerajinan yang hasilnya berupa kerajina keset dan batik ciprat. Pendampingan partisipatori pada masyarakat tunagrahita merupakan salah satu pemberdayaan masyarakat yang mengembangkan potensi-potensi masyarakat tunagrahita untuk lebih mandiri dalam memenuhi kebutuhan pribadinya. Pengembangan masyarakat akan berdampak pada kehidupan masyarakart baik secara positif maupun negatif (Hermawan, 2016).

Hasil dari pendampingan partisipatori telah dideskripsikan diatas. Dari pendampingan partisipatori tidak hanya hasil, namun jadi dampak secara langsung maupun tidak langsung. pendampingan partisipatori berdampak pada desa Karangpatihan, yang dikenal dengan "Kampung Idiot" oleh masyarakat sekitar. Selain itu, terjadinya dampak pada kehidupan masyarakat yang dilihat dari ekonomi masyarakat, kesehatan dan kehidupan sehari-hari masyarakat. Dampak ekonomi pada masyarakat yakni mampu memberikan kesempatan masyarakat untuk memenuhi kebutuhan masyarakat secara mandiri, seperti pupuk tanaman dan kebutuhan pokok lainnya.

\section{SIMPULAN}

Berdasarkan temuan penelitian yang diperoleh dari lapangan dan hasil pembahasan yang dilakukan peneliti mengenai pendampingan partisipatori dalam meningkatkan kemandirian masyarakat tunagrahita. Maka peneliti dapat menyimpulkan sebagai berikut.

Pertama, proses pendampingan masyarakat tunagrahita dilakukan secara intensif dengan mendatangi ke rumah-rumah masyarakat tunagrahita. Proses tersebut dilakukan berulang-ulang untuk memberikan kebiasaan atau pemahaman kepada masyarakat tungrahita. Tujuan mendatangi ke rumah-rumah adalah agar masyarakat lebih siap untuk melanjutkan kepada pemberian pelatihan-pelatihan. Pelatihan-pelatihan dan berkunjung kerumah dilakukan tidak hanya sekali untuk menimbulkan kebiasaan pada masyarakat tunagrahita sehingga masyarakat tunagrahita memahami materi yang disampaikan. 
Kedua, pendampingan dalam meningkatkan kemampuan, melalui pelatihan-pelatihan budidaya ayam, lele, dan kambing, serta pelatihan-pelatihan pembuatan kerajinan berupa keset dan batik ciprat. Pendamping mengklasifikasikan atau mengkelompokan masyarakat tunagrahita menjadi tiga yaitu ringan, sedang, dan berat. Pokmas Karangpatihan Bangkit dalam pelaksanaannya pembelajaran atau pelatihan mempunyai metode pendampingan yang berbeda dalam pelaksanaan pelatihan umumnya. Pendampingan masyarakat tunagrahita menggunakan pendekatan, pemahaman, dan penekanan.

Ketiga, pendampingan partisipatori mempunyai hasil dan dampak pada masyarakat tunagrahita. Hasil pendampingan partisipatori masyarakat tunagrahita adalah kerajinan-kerajinan yang dilatihkan oleh pedamping untuk meningkatkan pendampatan masyarakat berupa kerajinan keset dan batik ciprat. Selain itu, pendampingan juga berdampak pada sebutan desa Karangpatihan yang dikenal dengan "kampung idiot". Dampak lainnya adalah peningkatan ekonomi masyarakat. Dengan pendampingan yang dilakukan mampu memberikan kesempatan masyarakat untuk memenuhi kebutuhan masyarakat secara mandiri, yaitu berupa pupuk tanaman dan kebutuhan pokok lainnya.

Berdasarkan paparan data, temuan penelitian dan pembahasan maka dapat dikemukakan beberapa saran sebagai berikut. Pertama, bagi lembaga Pokmas Karangpatihan Bangkit. Berdasarkan pembahasan dan kesimpulan diatas maka peneliti memberikan saran terhadap pendampingan yang dilakukan oleh Pokmas Karangpatihan Bangkit. Dalam pendampingan yang dilakukan diharapkan meningkatkan pelaksanaan dalpendampingan masyarakat tunagrahita. Selain meningkatkan pelaksanaan dalam pendampingan, diharapkan Pokmas Karangpatihan Bangkit membuat perencanaan pembelajaran yang berisikan materi dan standar capaian yang harus dimiliki oleh masyarakat tunagrahita sehingga dapat mengetahui seberapa banyak masyarakat yang sudah memahami materi yang disampaikan.

Kedua, bagi jurusan Pendidikan Luar Sekolah. Dari penelitian ini dapat menjadi informasi baru bagi Pendidikan Luar Sekolah mengenai pendampingan partisipatori dalam meningkatkan kemandirian masyarakat tunagrahita yang dilakukan kelompok dan dapat memperkaya pengetahuan tentang bagaimana pendampingan dilakukan secara langsung untuk masyarakat tunagrahita.

Ketiga, bagi peneliti lain. Dari penelitian ini semoga peneliti lain dapat menjadikan dasar penelitian selanjutnya, karena di kelompok-kelompok masih terdapat banyak keunikan dan permasalahan yang dapat ditelusuri. Salah satunya mengenai interaksi sosial.

\section{DAFTAR RUJUKAN}

Ambaryanti, R. (2013). Hubungan Intensitas Pendampingan Belajar Orangtua dengan Kualitas Hasil Belajar Siswa di RA AlIslam Mangunsari 02 Semarang Tahun Pelajaran 2011/2012. Indonesian Journal of Early Childhood Education Studies, 2(2), 43-49.

Amila, A. (2017). Pemberdayaan Ekonomi Masyarakat Tunagrahita melalui Kelompok Swadaya Masyarakat Rumah Harapan Karangpatihan Bangkit: Studi Kasus di Desa Karangpatihan Kecamatan Balong Kabupaten Ponorogo. Tesis tidak diterbitkan. UIN Maulana Malik Ibrahim, Malang.

Anwas, O. M. (2013). Pemberdayaan Masyarakat di Era Global. Bandung: Alfabeta.

Britha, M. (1999). Metode Penelitian Partisipatoris dan Upaya-upaya Pemberdayaan: Sebuah Buku Pegangan Bagi Para Praktisi Lapangan (Vol. 438). Jakarta: Yayasan Obor Indonesia.

Dewi, D. S. K. (2016). Model Pemberdayaan Masyarakat Tunagrahita di Kampung Idiot Kabupaten Ponorogo. Otoritas: Jurnal Ilmu Pemerintahan, 6(1), 21-27. https://doi.org/10.26618/ojip.v6i1.35

Efendi, M. (2006). Pengantar Psikopedagogik Anak Berkelainan. Jakarta: Bumi Aksara.

Fitriagi, B. (2012). Tipe Produk Sosial Sebagai Pesan Komunikasi Dalam Penyelenggaraan Kegiatan Sadar Lingkungan (Studi pada Komunitas Earth Hour Malang). Skripsi tidak diterbitkan. Universitas Muhammadiyah Malang, Malang.

Haryeti, E., Sopandi, A. A., \& Iswari, M. (2013). Meningkatkan Keterampilan Membuat Palai Rinuak melalui Metode Latihan pada Anak Tunagrahita Ringan. Jurnal Penelitian Pendidikan Khusus, 2(3), 537-547.

Hermawan, H. (2016). Dampak pengembangan Desa Wisata Nglanggeran terhadap Ekonomi Masyarakat Lokal. Jurnal Pariwisata, 3(2), 105-117.

Huraerah, A. (2008). Pengorganisasian dan Pengembangan Masyarakat: Model \& Strategi Pembangunan Berbasis Kerakyatan. Bandung: Humaniora.

Ife, J., \& Tesoriero, F. (2008). Community Development: Alternatif Pengembangan Masyarakat di Era Globalisasi. Yogyakarta: Pustaka Belajar.

Jamaris. (2016). Kompetensi Pendamping Pembangunan Desa. Prosiding Seminar Nasional Jurusan Pendidikan Luar Sekolah, Fakultas Ilmu Pendidikan, Universitas Negeri Padang.

Karsidi, R. (2007). Pemberdayaan Masyarakat untuk Usaha Kecil dan Mikro (Pengalaman Empiris di Wilayah Surakarta Jawa Tengah). Jurnal Penyuluhan, 3(2), 136-145. https://doi.org/10.25015/penyuluhan.v3i2.2161

Listiyaningsih, R., \& Dewayani, T. N. E. (2009). Kepercayaan Diri pada Orangtua yang Memiliki Anak Tunagrahita. Fakultas Psikologi Universitas Mercu Buana, Yogyakarta. 
Mappiare, Andi AT. (1992). Pengantar Konseling dan Psikoterapi. Jakarta: PT Raja Grafindo Persada.

Moedzakir, D. (2010). Metode Pembelajaran untuk Program-Program Pendidikan Luar Sekolah. Malang: Universitas Negeri Malang.

Oktavini, C., \& Irdamurni, Z. (2013). Melatih Keterampilan Merangkai Bunga Akrilik melalui Metode Bervariasi bagi Anak Tunagrahita Ringan. Jurnal Penelitian Pendidikan Khusus, 2(3), 117-128.

Priyanti, M. M., Sudariyah, S., Mahmudah, L., \& Salimi, M. (2016). Upaya Pemberdayaan Anak Berkebutuhan Khusus melalui Pembelajaran Kewirausahaan di SLB Negeri Purworejo. Prosiding Seminar Nasional Inovasi Pendidikan, $403-410$.

Rachman, Z. M. (2007). Buku 2-Panduan untuk Fasilitator Infomobilisasi: Mengelola Program Infomobilisasi. Jakarta: Tim Partnerships for e-Prosperity for the Poor (Pe-PP).

Rasyad, A. (2014). The Implementation of Training Management Applied by the PNPM Mandiri Perkotaan Facilitator to SelfHelp Groups. IOSR Journal of Humanities and Social Science, 19(10), 9-13.

Rasyad, A., \& Suparna, B. (2003). Pengembangan dan Pemberdayaan Masyarakat. Malang: UM Press.

Suharto, E. (2005). Membangun Masyarakat, Memberdayakan Rakyat: Kajian Strategis Pembangunan Kesejahteraan Sosial dan Pekerjaan Sosial. Bandung: Refika Aditama.

Sumpeno, W. (2009). Menjadi Fasilitator Genius: Kiat-Kiat dalam Mendampingi Masyarakat. Jakarta: Exellent Learning Managemen Center.

Theresia, A. (2014). Pembangunan Berbasis Masyarakat. Bandung: Alfabeta.

Totok, M., \& Poerwoko, S. (2015). Pemberdayaan Masyarakat Dalam Perspektif Kebijakan Publik. Bandung: Alfabeta.

Triono, B. (2018). Kebijakan Pemberdayaan Masyarakat Difabel Idiot di Desa Karangpatihan Kecamatan Balong Kabupaten Ponorogo Jawa Timur. Jurnal Ilmu Administrasi Publik, 5(1), 94-107.

Ulfatin, N. (2013). Metode Penelitian Kualitatif di Bidang Pendidikan: Teori dan Aplikasinya. Malang: Fakultas Ilmu Pendidikan Universitas Negeri Malang.

Wrihatnolo, R. R., \& Dwidjowijoto, R. N. (2007). Manajemen Pemberdayaan: Sebuah Pengantar dan Panduan untuk Pemberdayaan Masyarakat. Jakarta: PT Gramedia. 